Published in final edited form as:

Nature. 2011 April 14; 472(7342): 186-190. doi:10.1038/nature09975.

\title{
Loss-of-function mutations in sodium channel $\mathrm{Na}_{\mathrm{v}} 1.7$ cause anosmia
}

\author{
Jan Weiss ${ }^{1},{ }^{*}$, Martina Pyrski ${ }^{1},{ }^{*}$, Eric Jacobi ${ }^{1}$, Bernd Bufe ${ }^{1}$, Vivienne Willnecker ${ }^{2}$, Bernhard \\ Schick $^{2}$, Philippe Zizzari ${ }^{3}$, Samuel J. Gossage ${ }^{4}$, Charles A. Greer ${ }^{5}$, Trese Leinders-Zufall ${ }^{1}$, \\ C. Geoffrey Woods ${ }^{6}$, John N. Wood ${ }^{4,7}$, and Frank Zufall ${ }^{1}$ \\ ${ }^{1}$ Department of Physiology, University of Saarland School of Medicine, 66421 Homburg, \\ Germany \\ ${ }^{2}$ Department of Otolaryngology, University of Saarland School of Medicine, $66421 \mathrm{Homburg}$, \\ Germany \\ ${ }^{3}$ Centre de Psychiatrie \& Neurosciences, UMR 894 Inserm, Faculté de Médecine, Université \\ Paris Descartes, 75014 Paris, France \\ ${ }^{4}$ Molecular Nociception Group, Wolfson Institute for Biomedical Research, University College \\ London, London WC1E 6BT, UK \\ ${ }^{5}$ Department of Neurosurgery, Yale University School of Medicine, New Haven, Connecticut \\ 06520, USA \\ ${ }^{6}$ Department of Medical Genetics, Cambridge Institute for Medical Research, Wellcome/MRC \\ Building, Addenbrooke's Hospital, Cambridge CB2 OXY, UK \\ ${ }^{7}$ Department of Molecular Medicine and Biopharmaceutical Sciences, Seoul National University, \\ Seoul 151-742, Korea
}

\section{Abstract}

Loss of function of the gene $S C N 9 A$, encoding the voltage-gated sodium channel $\mathrm{Na}_{\mathrm{v}} 1.7$, causes a congenital inability to experience pain in humans. Here we show that $\mathrm{Na}_{\mathrm{v}} 1.7$ is not only necessary for pain sensation but is also an essential requirement for odour perception in both mice and humans. We examined human patients with loss-of-function mutations in $S C N 9 A$ and show that they are unable to sense odours. To establish the essential role of $\mathrm{Na}_{\mathrm{v}} 1.7$ in odour perception, we generated conditional null mice in which $\mathrm{Na}_{\mathrm{v}} 1.7$ was removed from all olfactory sensory neurons. In the absence of $\mathrm{Na}_{\mathrm{v}} 1.7$, these neurons still produce odour-evoked action potentials but fail to initiate synaptic signalling from their axon terminals at the first synapse in the olfactory system. The mutant mice no longer display vital, odour-guided behaviours such as innate odour

C2011 Macmillan Publishers Limited. All rights reserved

Correspondence and requests for materials should be addressed to F.Z. (frank.zufall@uks.eu).

These authors contributed equally to this work.

Full Methods and any associated references are available in the online version of the paper at www.nature.com/nature.

Supplementary Information is linked to the online version of the paper at www.nature.com/nature.

Author Contributions J.N.W. and F.Z. conceived the study. J.W., M.P., E.J., B.B. and P.Z. performed experiments. B.S. performed human biopsies. C.G.W., S.J.G. and J.N.W. performed human smell tests. J.W., M.P., E.J., B.B., V.W., P.Z., S.J.G., C.A.G., T.L.-Z., C.G.W., J.N.W. and F.Z. analysed results. M.P., T.L.-Z., J.N.W. and F.Z. contributed key reagents. F.Z. wrote the manuscript. All authors edited the manuscript.

Reprints and permissions information is available at www.nature.com/reprints.

The authors declare no competing financial interests.

Readers are welcome to comment on the online version of this article at www.nature.com/nature. 
recognition and avoidance, short-term odour learning, and maternal pup retrieval. Our study creates a mouse model of congenital general anosmia and provides new strategies to explore the genetic basis of the human sense of smell.

The inability to sense odours is known as general anosmia; individuals born with this phenotype are afflicted with congenital general anosmia. Except for some syndromic cases such as Kallmann syndrome, no causative genes for human congenital general anosmia have been identified so $\mathrm{far}^{1-3}$. Nine mammalian genes encoding voltage-gated sodium channel asubunits have been cloned and shown to be differentially expressed in the nervous system ${ }^{4,5}$. Of these, $S C N 9 A$, encoding the tetrodotoxin (TTX)-sensitive sodium channel $\mathrm{Na}_{\mathrm{v}} 1.7$, has received specific attention because of its key role in human pain perception. Individuals carrying loss-of-function mutations in $S C N 9 A$ are unable to experience pain, and an essential requirement of $\mathrm{Na}_{\mathrm{v}} 1.7$ function for nociception in humans has been established ${ }^{6-9}$. Whether all other sensory modalities are fully preserved in these individuals remained unclear, although an association between congenital inability to experience pain and sense of smell deficits has been suggested ${ }^{7}$. In this study we examine human patients carrying $S C N 9 A$ loss-of-function mutations and demonstrate that they fail to sense odours. We establish a mouse model of congenital general anosmia and provide mechanistic insight into the role of $\mathrm{Na}_{\mathrm{v}} 1.7$ in olfaction. Together with previous findings ${ }^{6-8,10}$, our results establish that loss-of-function mutations in a single gene, $S C N 9 A$, cause a general loss of two major senses-nociception and smell-thus providing a mechanistic link between these two sensory modalities.

\section{Requirement for $\mathrm{Na}_{\mathrm{v}} 1.7$ in human olfaction}

Three individuals with congenital analgesia were ascertained and studied. All three were in their third decade of life and had never experienced acute pain but had no other neurological, cognitive, growth, appearance or health problems. All had suffered from multiple painless fractures and other injuries. Two had given birth painlessly. A working diagnosis of channelopathy-associated insensitivity to pain (CAIP) was made and in each $S C N 9 A$ was sequenced ${ }^{6}$. In the first, who has been the subject of a detailed case report, the mutations c.774_775delGT and c.2488C $>\mathrm{T}$ were found ${ }^{10}$. These mutations, frameshift and nonsense, respectively, would be predicted to lead to a lack of functional $\mathrm{Na}_{\mathrm{v}} 1.7$ protein. The other two were siblings and had the mutations c.4975A $>\mathrm{T}$ and $\mathrm{c}$.

3703delATAGCATATGG; again, nonsense and frameshift mutations and predicted to lead to no functional $\mathrm{Na}_{\mathrm{v}} 1.7$ protein. The mother of the siblings was found to be heterozygous for the 11-base-pair deletion and the father heterozygous for the nonsense mutation. Therefore the diagnosis of CAIP was substantiated. We next assessed their sense of smell; none complained of having no sense of smell, one had been a cigarette smoker, none had chronic nasal problems. In the first woman smell function was assessed by using the University of Pennsylvania Smell Identification Test (UPSIT), a standardized 40-item smell test. The results revealed that she was unable to detect any of the odours (Fig. 1a, black bar). Nine healthy, young individuals served as controls (Fig. 1a, grey bars). In the sibling pair we assessed the parents and their two affected offspring together. All were tested in sequence with cotton wool pads suffused with selected odour stimuli: balsamic vinegar, orange, mint, perfume, water (control) and coffee. Both parents correctly identified all stimuli, including smelling nothing for the water. The siblings detected none of the odours. For the siblings the test was repeated using subjectively unpleasant amounts of balsamic vinegar and perfume: the parents identified the odours correctly and found them unpleasant; the siblings neither identified the odours nor experienced any discomfort.

We proposed that these odour-sensing deficits are caused by loss of $\mathrm{Na}_{\mathrm{v}} 1.7$ function in olfactory sensory neurons (OSNs). Indeed, when we investigated expression of $\mathrm{Na}_{\mathrm{v}} 1.7$ in 
normal human olfactory epithelium, we detected messenger RNA for $\mathrm{Na}_{\mathrm{v}} 1.7$ and the GTPbinding protein $\mathrm{Ga}_{\mathrm{olf}}$, a prototypical signature of classical OSNs (Fig. 1b).

Immunohistochemistry using an antibody specific to $\mathrm{Na}_{\mathrm{v}} 1.7$ verified that $\mathrm{Na}_{\mathrm{v}} 1.7$ is normally expressed in human OSNs (Fig. 1c, d).

\section{Conditional $\mathrm{Na}_{\mathrm{v}} 1.7$ null mice}

To investigate the mechanisms that underlie the essential role of $\mathrm{Na}_{\mathrm{v}} 1.7$ in odour perception, we first examined $\mathrm{Na}_{\mathrm{v}} 1.7$ expression in the mouse olfactory system and then used the Crelox $P$ system to delete the channel in those cells that express olfactory marker protein (OMP), which includes all classical OSNs ${ }^{11}$. These mice enabled us to examine the mechanisms underlying $\mathrm{Na}_{\mathrm{v}} 1.7$-associated anosmia and thebehavioural consequences. Consistent with our findings in human OSNs, OSNs from wild-type mice (C57BL/6, referred to as B6) showed $\mathrm{Na}_{\mathrm{v}} 1.7$ immunoreactivity at their somata (Supplementary Fig. 1). Of greater interest, coronal sections containing main olfactory epithelium (MOE), olfactory nerves and the two olfactory bulbs revealed the most marked $\mathrm{Na}_{\mathrm{v}} 1.7$ staining in the superficial olfactory nerve layer (ONL, containing axons from OSNs) as well as the glomerular layer (a complex neuropil that includes the presynaptic OSN boutons) of the olfactory bulb (Fig. 2a-c). Higher magnification of individual glomeruli verified co-expression of $\mathrm{Na}_{\mathrm{v}} 1.7$ with OMP in the glomerular neuropil (Fig. 2b), whereas olfactory bulb projection neurons (the mitral/ tufted or M/T cells) and local interneurons did not show $\mathrm{Na}_{\mathrm{v}} 1.7$ immunoreactivity (Fig. 2a). Thus, $\mathrm{Na}_{\mathrm{v}} 1.7$ occupies a critical presynaptic location at the first synapse in the olfactory system.

$\mathrm{Na}_{\mathrm{v}} 1.7$ is not the sole $\mathrm{Na}_{\mathrm{v}}$ channel expressed in mouse OSNs. Real-time quantitative polymerase chain reaction with reverse transcription (qRT-PCR) analysis identified $\mathrm{Na}_{\mathrm{v}} 1.3$ as an additional candidate (Supplementary Fig. 2) and immunohistochemistry verified its expression in OSNs and their axons (Fig. 2d). However, unlike $\mathrm{Na}_{\mathrm{v}} 1.7$ we did not observe $\mathrm{Na}_{\mathrm{v}} 1.3$ immunoreactivity in individual glomeruli (Fig. 2d), indicating that $\mathrm{Na}_{\mathrm{v}} 1.7$ could be the sole $\mathrm{Na}_{\mathrm{v}}$ channel underlying action potential propagation in olfactory glomeruli and OSN nerve terminals.

To create a conditional knockout mouse model, we crossed 'floxed' $\mathrm{Na}_{\mathrm{v}} 1.7$ mice harbouring a $\operatorname{lox} P$-flanked $S c n 9$ a gene 12 to homozygous OMP-Cre mice in which the OMP-coding region is replaced by that of Cre recombinase ${ }^{13}$. Further breeding established offspring that were both homozygous for the floxed $S c n 9 a$ alleles and heterozygous for cre and $O m p$. In these mice, Cre-mediated $\mathrm{Na}_{\mathrm{v}} 1.7$ deletion was restricted to OMP-positive cells (henceforward referred to as $\mathrm{cNa}_{\mathrm{v}} 1.7^{-/-}$mice). These mice lacked $\mathrm{Na}_{\mathrm{v}} 1.7$ expression in a tissue-specific manner (Fig. 2e, f and Supplementary Fig. 3). Successful matings occurred between $\mathrm{cNa}_{\mathrm{v}} 1.7^{+/-}$males and $\mathrm{cNa}_{\mathrm{v}} 1.7^{-/-}$zygous knockout females whereas homo-pairs did not produce any offspring. $\mathrm{cNa}_{\mathrm{v}} 1.7^{-/-}$mice showed a reduced body weight during the first three months of postnatal development (Supplementary Fig. 4a). Because both $\mathrm{Na}_{\mathrm{v}} 1.7$ (refs 14, 15) and OMP16 are also expressed in some neurons mediating hormonal regulation, we assayed insulin-like growth factor (IGF-1, also known as somatomedin C) in $\mathrm{cNa}_{\mathrm{v}} 1.7^{-/-}\left(650 \pm 94 \mathrm{ng} \mathrm{ml}^{-1} ; n=4\right)$ versus $\mathrm{cNa}_{\mathrm{v}} 1.7^{+/-}$mice $\left(684 \pm 27 \mathrm{ng} \mathrm{ml}^{-1} ; n=4\right.$; mean \pm s.d.) but found no significant difference between the two genotypes $(P=0.26)$. Given that newborn $\mathrm{cNa}_{\mathrm{v}} 1.7^{-/-}$mice had very little milk in their stomachs (Supplementary Fig. 4b), the diminished weight gain was probably caused by a deficit to suckle effectively, consistent with results in mice deficient in $\mathrm{Ga}_{\text {olf }}$ ( $G n a l$ ) or the cAMP-gated cation channel (Cnga2) $^{17,18}$. 


\section{Loss of synaptic transfer in olfactory glomeruli}

To define the function of $\mathrm{Na}_{\mathrm{v}} 1.7$ in OSNs, we prepared MOE tissue slices ${ }^{19}$ and recorded sodium currents in voltage-clamped OSNs. Both $\mathrm{Na}_{\mathrm{v}} 1.7^{+/-}$and $\mathrm{Na}_{\mathrm{v}} 1.7^{-/-}$OSNs displayed sizeable, TTX-sensitive sodium currents in response to step depolarizations (Fig. 3a, b). On the basis of its biophysical properties, $\mathrm{Na}_{\mathrm{v}} 1.7$ has been suggested to transduce generator potentials into action potentials in sensory neurons ${ }^{9}$. However, peak current densities of voltage-activated sodium currents were reduced only moderately, by about $20 \%$, in $\mathrm{Na}_{\mathrm{v}} 1.7^{-/-}$OSNs (Fig. 3b). To determine whether $\mathrm{Na}_{\mathrm{v}} 1.7^{-/-}$OSNs could still produce odourevoked action potentials, we used extracellular loose-patch recording from visually identified OSN dendritic knobs ${ }^{20}$ and analysed spike frequency histograms after brief odour exposure (Fig. 3c). There was no obvious difference in odour responsiveness in $\mathrm{Na}_{\mathrm{v}} 1.7^{-/-}$ versus $\mathrm{Na}_{\mathrm{v}} 1.7^{+/-}$OSNs (Fig. 3c). We obtained similar results when we stimulated the cells with 3-isobutyl-1-methylxanthine (IBMX) ${ }^{21}$, which raises intracellular cAMP by inhibiting endogenous phosphodiesterase activity (Fig. 3c). Thus, although the initial site of odourevoked action potential generation in OSNs is unknown, $\mathrm{Na}_{\mathrm{v}} 1.7$ is not essential for this activity.

Because $\mathrm{Na}_{\mathrm{v}} 1.7$ is expressed in olfactory bulb glomeruli (Fig. 2), we reasoned that it could be required for action potential conduction in OSN terminals. Olfactory glomeruli are delineated spheres of neuropil containing synapses from the OSN axon terminals onto juxtaglomerular interneurons and $\mathrm{M} / \mathrm{T}$ projection neurons ${ }^{22,23}$. To examine whether presynaptic activity of $\mathrm{Na}_{\mathrm{v}} 1.7$ underlies transmitter release in the olfactory glomerulus, we prepared olfactory bulb tissue slices ${ }^{24}$ and combined ONL focal electric stimulation with whole-cell patch-clamp recording from visually identified $\mathrm{M} / \mathrm{T}$ cells. With the chosen protocol, in control $\mathrm{cNa}_{\mathrm{v}} 1.7^{+/-}$mice a single electrical stimulus in the ONL produced a reliable postsynaptic response in $\mathrm{M} / \mathrm{T}$ cells. Under current clamp, such responses consisted of a prolonged excitation lasting on average for $2.4 \pm 0.4 \mathrm{~s}$ (Fig. 3d, top; $n=29$ ), with response latencies of $22 \pm 4 \mathrm{~ms}(n=29)$. Under voltage clamp, we observed bursts of postsynaptic currents (Fig. 3f; duration, $3.2 \pm 0.4 \mathrm{~s} ; n=26$ ). In stark contrast, in the $\mathrm{cNa}_{\mathrm{v}} 1.7^{-/}$mice such postsynaptic responses were virtually absent in $\mathrm{M} / \mathrm{T}$ cells, even when the stimulus strength was increased by several-fold (Fig. 3d-f; $n=49$ ). Importantly, M/T cells in these mice still produced normal action potentials when depolarized via current injection through the patch pipette (Fig. 3d, bottom), consistent with the fact that M/T cells lack both OMP and $\mathrm{Na}_{\mathrm{v}} 1.7$ expression (Fig. 2) and indicating that the effect of deleting $\mathrm{Na}_{\mathrm{v}} 1.7$ is presynaptic to the $\mathrm{M} / \mathrm{T}$ cells. The inability of M/T cells to produce synaptic responses to ONL stimulation was not due to a potential deficit in synapse formation because: (1) immunohistochemistry showed normal expression of the vesicular glutamate transporter 2 (vGluT2, which is selectively expressed in OSN axon terminals) ${ }^{25,26}$ (Supplementary Fig. 5); and (2) electron microscopy revealed the existence of normal OSN boutons and synapses in the glomeruli of $\mathrm{cNa}_{\mathrm{v}} 1.7^{-/-}$mice (Supplementary Fig. 6). Furthermore, conditional OSN expression of tetanus toxin light chain, which inhibits synaptic release, does not alter the pattern of axonal targeting in olfactory bulb glomeruli during development ${ }^{27}$.

Tyrosine hydroxylase (TH) expression in juxtaglomerular neurons of the olfactory bulb, a correlate of afferent trans-synaptic activity, requires olfactory nerve input and odourstimulated glutamate release by OSN terminals ${ }^{28}$. Consistent with a loss of OSN synaptic release, TH expression was markedly reduced in $\mathrm{cNa}_{\mathrm{v}} 1.7^{-/}$mice (Fig. $3 \mathrm{~h} ; n=6$ ). The level of TH downregulation was similar to that observed after odour deprivation by naris occlusion $^{29}$ or after deletion of the Cnga2 cation channel gene ${ }^{30}$. Thus, we conclude that the presence of $\mathrm{Na}_{\mathrm{v}} 1.7$ in OSN axons is an essential and non-redundant requirement to initiate information transfer from OSN terminals to neurons in the olfactory bulb. 


\section{The absence of odour-guided behaviours}

To further validate these results, we investigated several odour-guided behaviours in B6, $\mathrm{cNa}_{\mathrm{v}} 1.7^{+/-}$and $\mathrm{cNa}_{\mathrm{v}} 1.7^{-/-}$mice. First, we performed an odour preference test ${ }^{31}$ to assess recognition abilities for innate odour qualities (Fig. 4a). Filter papers scented with various cues representing both species-specific and food odours (male and female urine, peanut butter, milk) were presented to the mice and investigation times were analysed. Water was used as a neutral stimulus and 1,8-cineole (eucalyptol), which does not evoke innate attraction, served as the control ( $n \geq 7$ for each cue and strain, respectively). B6 and $\mathrm{cNa}_{\mathrm{v}} 1.7^{+/-}$mice both showed strong attraction towards con-specific and food odours, whereas $\mathrm{cNa}_{\mathrm{v}} 1.7^{-/-}$mice failed to show any interest in these stimuli.

Second, we explored whether $\mathrm{Na}_{\mathrm{v}} 1.7$ is required for innate avoidance behaviour towards a predator odour, trimethyl-thiazoline (TMT) ${ }^{31}$, which is normally secreted from the fox anal gland and known to induce aversive behaviour and fear responses in mice. We observed robust avoidance behaviour in both $\mathrm{B} 6(n=6)$ and $\mathrm{cNa}_{\mathrm{v}} 1.7^{+/-}$mice $(n=5)$ but, notably, $\mathrm{cNa}_{\mathrm{v}} 1.7^{-/-}$mice lacked an innately aversive response in this assay $(n=5$; Fig. $4 \mathrm{~b}, \mathrm{c})$.

Third, we investigated the performance of $\mathrm{cNa}_{\mathrm{v}} 1.7^{-/-}$mice in a habituation-dishabituation assay, which allows for measurement of novel odour investigation, short-term odour learning, and odour discrimination ${ }^{32}$ (Fig. 4d). Mice of both sexes were each presented three distinct stimuli (water, female urine, male urine), each delivered for three successive trials, and investigation time during each trial $(3 \mathrm{~min})$ mice was analysed. Consistent with the results of Fig. $4 \mathrm{a}, \mathrm{cNa}_{\mathrm{v}} 1.7^{-/-}(n=8)$ failed to show significant odour investigation, habituation, or discrimination abilities when compared with $\mathrm{B} 6(n=8)$ or $\mathrm{cNa}_{\mathrm{v}} 1.7^{+/-}$mice $(n=8)$ (Fig. 4d; least significant difference (LSD), $P<0.0001)$.

Last, we examined pup retrieval ability of female mice, a social behaviour that probably depends on a functional main olfactory system (Fig. 4e). Three pups of a litter were removed from the nest, randomly distributed in the cage, and the time to retrieve each pup into the nest was quantified. In contrast to the performance of $\mathrm{B} 6(n=12)$ or $\mathrm{cNa}_{\mathrm{v}} 1.7^{+/-}$mice $(n=$ $6), \mathrm{cNa}_{\mathrm{v}} 1.7^{-/-}$mice $(n=5)$ failed to retrieve any of the three pups during a 10-min trial period (Fig. 4e).

\section{Conclusions and prospects}

Our results establish a critical role of the $\mathrm{Na}_{\mathrm{v}} 1.7$ sodium channel in olfaction. Using conditional $\mathrm{Na}_{\mathrm{v}} 1.7$ null mice, we demonstrate that, in the absence of $\mathrm{Na}_{\mathrm{v}} 1.7$, OSNs are still electrically active and generate odour-evoked action potentials but fail to initiate synaptic signalling to the projection neurons in the olfactory bulb. These results provide evidence that $\mathrm{Na}_{\mathrm{v}} 1.7$ is an essential and non-redundant requirement for action potential propagation in the sections of OSN axons within the olfactory glomerulus. The conditional null mice no longer show a wide range of vital, odour-guided behaviours including innate attraction to food and conspecific odours, odour discrimination and short-term odour learning, innate avoidance towards a predator odour, effective suckling behaviour of newborn pups, and maternal pup retrieval. Within the limits of our anatomical analyses, synapse formation in these mice appears normal, indicating that the behavioural phenotype of the mutant mice is most likely the result of a loss of signalling at the first synapse in the olfactory system. Whether $\mathrm{Na}_{\mathrm{v}} 1.7$ or other sodium channel subunits such as $\mathrm{Na}_{\mathrm{v}} 1.3$ are involved in OSN axon pathfinding and activity-dependent neural map formation ${ }^{33}$ in the mouse olfactory system remains to be seen. Importantly, the phenotype of the mutant mice - the inability to perceive odours-is similar to that observed in human patients with confirmed $\mathrm{Na}_{\mathrm{v}} 1.7$ loss-of-function mutations. Smell tests in three individuals with congenital analgesia establish that they are 
unable to sense any of the odours. Systematic olfactory testing of patients carrying $\mathrm{Na}_{\mathrm{v}} 1.7$ loss-of-function mutations will be required in the future.

The genetic basis of sensory deficits such as blindness, deafness and pain disorders has been extensively studied in recent years. By comparison, relatively little progress has been made in understanding human congenital general anosmia ${ }^{1}$. Mutations in olfactory signal transduction genes such as $C N G A 2, G N A L$ and $A D C Y 3$ do not seem to be a major cause of human congenital general anosmia ${ }^{2}$. The identification of a sodium channel subunit as a causative gene for an inherited form of general anosmia provides new insight into the molecular pathophysiology of olfaction and should stimulate further research aimed at understanding the genetic basis of the human sense of smell.

\section{METHODS}

\section{Human biopsies}

Human nasal mucosa was obtained by biopsy during routine nasal surgery with patients under general anaesthesia. Biopsy specimens were obtained from three individuals and snapfrozen in liquid nitrogen for later processing. All samples were obtained under a protocol approved by the Ethics Committee of the University of Saarland School of Medicine. All biopsy tissues were obtained with the informed consent of the patients.

\section{Human psychophysics}

The UPSIT was obtained from Sensonics. The test was applied over a period of $25 \mathrm{~min}$. Testing and scoring was done according to standardized operating procedures summarized in the test manual. The reference values have been derived from recorded reference ranges for the UPSIT test based on British individuals.

\section{Olfactory mucosa biopsies and PCR analyses}

Human surgical material containing olfactory mucosa collected from three different patients was examined individually. RT-PCRs from human samples were performed on a MyCycler (BIO-RAD) with Herculase (Agilent Technologies) following suppliers' instructions. To amplify human $\mathrm{Ga}_{\text {olf }}$ we used the oligonucleotides TGGAAAGAATCGACAGCGTCAGC and GGCCACCAACATCAAACATGTGG. Human $\mathrm{Na}_{\mathrm{v}} 1.7$ was amplified by CATGAATAACCCACCGGACTG and CCTATGCCCTTCGACACCAAGG. PCR conditions were: $95{ }^{\circ} \mathrm{C}$ for 2 min pre-denaturation, followed by 35 cycles $\left(95^{\circ} \mathrm{C}\right.$ for $30 \mathrm{~s}, 60$ ${ }^{\circ} \mathrm{C}$ for $30 \mathrm{~s}\left(\mathrm{Ga}_{\text {olf }}\right)$ or $1 \mathrm{~min}\left(\mathrm{Na}_{\mathrm{v}} 1.7\right), 72{ }^{\circ} \mathrm{C}$ for $\left.30 \mathrm{~s}\right)$, followed by a final extension $72{ }^{\circ} \mathrm{C}$ for 5 min. Mouse tissue was pooled from four different B6 mice (4-8 weeks old). RNA was isolated with the InnuPREP RNA isolation kit (Analyticjena). RNA quality was assessed by gel electrophoresis and photometric measurements. cDNA was synthesized from $0.5 \mu \mathrm{g}$ of total RNA using the Smart cDNA Synthesis technology (Clontech) and Supercript II reverse transcriptase (Invitrogen). qPCR for different mouse $\mathrm{Na}_{\mathrm{v}}$ subunits were done on a My-iQcycler using $\mathrm{iQ}^{\mathrm{TM}} \mathrm{SYBRG}$ reen Supermix following the supplier's instructions (BIO-RAD). We used the following oligo-nucleotides: $\mathrm{Na}_{\mathrm{v}} 1.1$ (AGCCTGGTAGAACTTGGCCTTGC and TGCCAACCA CGGCAAAAATAAAG); $\mathrm{Na}_{\mathrm{v}} 1.2$ (TGGGATCTTCACCGCAGAAATG and TGGGCCAGGATTTTGCCAAC); (AGCTTGGCCTGGCAAACGTG $\mathrm{Na}_{\mathrm{v}} 1.3$ and ATGCCGACCACGGCAAAAATG); $\mathrm{Na}_{\mathrm{v}} 1.5$ (ACAGCCGAGTTTGAG GAGATGC and CGCTGATTCGGTGCCTCA); $\mathrm{Na}_{\mathrm{v}} 1.6$ (ACGCCACAATTC GAACATGTCC and CCTGGCTGATCTTACAGACGCA); $\mathrm{Na}_{\mathrm{v}} 1.7$ (ACGGAT GAATTCAAAAATGTACTTGCAG and GTTCTCGTTGATCTTGCAAACA CA). PCR conditions were: $95^{\circ} \mathrm{C}$ for 3 min pre-denaturation, followed by 42 cycles $95{ }^{\circ} \mathrm{C}$ for $30 \mathrm{~s}, 64{ }^{\circ} \mathrm{C}$ for $20 \mathrm{~s}, 72{ }^{\circ} \mathrm{C}$ for $30 \mathrm{~s}$. Each reaction was performed in three replicates on 
96-well plates and analysed with the iQ5 Software (BIO-RAD). Specificity of all PCR products was confirmed by gel electrophoresis and sequencing.

Mice

Animal care and experimental procedures were performed in accordance with the guidelines established by the animal welfare committee of the University of Saarland School of Medicine. Mice were kept under a standard light/dark cycle with food and water ad libitum. Tissue-specific, $\mathrm{Na}_{\mathrm{v}} 1$.7-deficient mice were generated by crossbreeding 'floxed' $\mathrm{Na}_{\mathrm{v}} 1.7$ mice that carry two loxP sites, flanking exons 14 and 15 of $S c n 9 a^{12}$ with homozygous

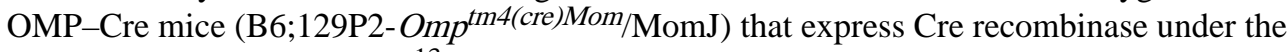
control of the OMP promoter ${ }^{13}$. Further breeding established offspring that were both homozygous for the floxed $\mathrm{Na}_{\mathrm{v}} 1.7$ alleles and heterozygous for cre and Omp. In these mice, Cre-mediated $\mathrm{Na}_{\mathrm{v}} 1.7$ deletion was restricted to OMP-positive cells. Additionally, C57BL/6J (B6) and OMP-GFP (B6;129P2-Omp $\left.p^{t m 3 M o m} / \mathrm{MomJ}\right)$ mice were used.

\section{Immunohistochemistry}

Perfusion of mice and preparation of mouse olfactory tissues for immunohistochemistry followed previously described methods ${ }^{34}$. Cryosections $(10-12 \mu \mathrm{m})$ of either human or mouse olfactory tissues were postfixed using $4 \%$ paraformaldehyde in PBS, before blocking and antibody administration. Primary antibodies were: mouse-specific anti-Na 1.7 (1:500, rabbit polyclonal; Millipore), human-specific anti- $\mathrm{Na}_{\mathrm{v}} 1.7$ (1:500, rabbit polyclonal; Abcam), $\mathrm{Na}_{\mathrm{v}} 1.3$ (1:500, rabbit polyclonal; Millipore), OMP (1:3,000, goat polyclonal; gift of F. Margolis), vGluT2 (1:2,000, rabbit polyclonal; Synaptic Systems), tyrosine hydroxylase (TH, 1:3,000, mouse monoclonal; ImmunoStar). Secondary antibodies and conjugated compounds were: Alexa-Fluor 488 donkey-anti-goat (1:1,000; Invitrogen), Alexa-Fluor 555 donkey-anti-rabbit (1:1,000; Invitrogen), Alexa-Fluor 546 Streptavidin (1:200; Invitrogen). Procedures were conducted at room temperature $\left(21^{\circ} \mathrm{C}\right)$, except for incubation in primary antibodies $\left(4{ }^{\circ} \mathrm{C}\right)$. Expression of $\mathrm{Na}_{\mathrm{v}} 1.7$ in human was detected by direct immunofluorescence. Expression of $\mathrm{Na}_{\mathrm{v}} 1.3$ and $\mathrm{Na}_{\mathrm{v}} 1.7$ in mouse was detected by tyramid signal amplification using manufacturer's protocol (TSA-Biotin System, Perkin Elmer). Incubation in primary antibody was for 2-3 days, in biotinylated anti-rabbit antibody (1:400; Jackson ImmunoResearch) for $1 \mathrm{~h}$, in streptavidin-HRP (1:100) for $30 \mathrm{~min}$, in biotinylated tryamid (1:100) for $10 \mathrm{~min}$, and visualized using Alexa 546-conjugated steptavidin (Invitrogen, 1:200). OMP colocalization was detected using a Alexa 488-conjugated antigoat secondary antibody. Detection of vGluT2 was exactly as previously described ${ }^{26}$. TH was detected in $30-\mu \mathrm{m}$ free-floating sections using the avidin-biotin method (Vectastain ABC-Elite, Vector). Incubation in primary TH antibody was for 1 day, in biotinylated horseanti-mouse secondary antibody (1:400, Vector Laboratories) for $1 \mathrm{~h}$, and in avidin/biotinHRP complex (Vector) for 90 min. Immunoreactivity was visualized with $0.05 \mathrm{~g} \mathrm{l}^{-1} 3,3^{\prime}$ diaminobenzidine and $0.015 \% \mathrm{H}_{2} \mathrm{O}_{2}$. Fluorescence images were acquired on either a $\mathrm{BX} 71$ microscope attached to a DP71 camera (Olympus) or an LSM 710/ConfoCor-3 microscope (Zeiss). Image stacks are presented as maximum intensity projections, assembled and minimally adjusted in brightness using Adobe PhotoShop 6.0.

\section{Electron microscopy}

Following routine processing for electron microscopy, as previously described ${ }^{26,35}$, thin 70 100-nm sections were cut on a Reichert Ultracut E and examined on a JEOL 1200 transmission electron microscope. Images were captured at $\times 12,000$, digitized at 1,200 dots per inch (DPI), and examined for ultrastructural features of the olfactory sensory axons and their synaptic terminals. 


\section{Electrophysiology}

Whole-cell patch-clamp recordings from individual OSNs were obtained in acute MOE tissue slices of P1-P5 mice ${ }^{19}$. The anterior aspect of the head containing olfactory epithelium and bulb was embedded in agarose (4\%), placed in oxygenated, ice-cold extracellular solution $\left(95 \% \mathrm{O}_{2}, 5 \% \mathrm{CO}_{2}\right)$ containing: $120 \mathrm{mM} \mathrm{NaCl}, 25 \mathrm{mM} \mathrm{NaHCO}_{3}, 5$ $\mathrm{mM} \mathrm{KCl}, 5 \mathrm{mM}$ BES ( $N, N$-bis[2-hydroxyethyl]-2-aminoethansulphonic acid), $1 \mathrm{mM}$ $\mathrm{MgSO}_{4}, 1 \mathrm{mM} \mathrm{CaCl}_{2}, 10 \mathrm{mM}$ glucose, osmolarity adjusted to $300 \mathrm{mOsm}, \mathrm{pH}$ 7.3. Coronal slices $(250 \mu \mathrm{m}$ ) were cut on a vibratome (Microm HM $650 \mathrm{~V}$ ), transferred to a recording chamber and kept under continuous flow $\left(2 \mathrm{ml} \mathrm{min}^{-1}\right)$ of oxygenated solution or remained on ice in oxygenated solution until needed (for up to $4 \mathrm{~h}$ ). Experiments were performed at room temperature. The CsCl-based electrode solution contained: $140 \mathrm{mM} \mathrm{CsCl}, 1 \mathrm{mM}$ EGTA, 10 mM HEPES, 0.5 mM GTP Na-salt, 2 mM ATP Mg-salt, pH 7.1, 290 mOsm. To assess OSN firing properties under non-invasive conditions, we used extracellular loosepatch recording from OSN $\mathrm{knobs}^{20}$. In this case, the septal epithelium of juvenile (P1-P5) or adult mice was dissected and transferred to a recording chamber. Patch pipettes (9-12 M $\Omega$ ) were filled with a HEPES-based extracellular solution containing: $140 \mathrm{mM} \mathrm{NaCl}, 5 \mathrm{mM}$ $\mathrm{KCl}, 1 \mathrm{mM} \mathrm{MgCl}, 1 \mathrm{mM} \mathrm{CaCl}_{2}, 10 \mathrm{mM}$ HEPES, pH 7.4, $300 \mathrm{mOsm}$. IBMX was prepared in $10 \mathrm{mM}$ stock solution containing 5\% dimethylsulphoxide (DMSO) (v/v). For M/T cell recordings, brains were rapidly dissected in ice-cold oxygenated $\left(95 \% \mathrm{O}_{2}, 5 \% \mathrm{CO}_{2}\right)$ solution containing: $83 \mathrm{mM} \mathrm{NaCl}, 26.2 \mathrm{mM} \mathrm{NaHCO} 3,1 \mathrm{mM} \mathrm{NaH}_{2} \mathrm{PO}_{4}, 2.5 \mathrm{mM} \mathrm{KCl}, 3.3 \mathrm{mM}$ $\mathrm{MgSO}_{4}, 0.5 \mathrm{mM} \mathrm{CaCl}_{2}, 70 \mathrm{mM}$ sucrose, $\mathrm{pH} 7.3,300 \mathrm{mOsm}$. Horizontal olfactory bulb slices $(300 \mu \mathrm{m})$ were cut in this solution. Until use, slices were transferred to oxygenated modified artificial cerebrospinal fluid (ACSF, 95\% $\mathrm{O}_{2}, 5 \% \mathrm{CO}_{2}$ ) containing: $125 \mathrm{mM} \mathrm{NaCl}$, $25 \mathrm{mM} \mathrm{NaHCO}_{3}, 2.5 \mathrm{mM} \mathrm{KCl}, 1.25 \mathrm{mM} \mathrm{NaH}_{2} \mathrm{PO}_{4}, 1 \mathrm{mM} \mathrm{MgCl} 2,2 \mathrm{mM} \mathrm{CaCl}_{2}$ and $25 \mathrm{mM}$ glucose. Recording pipettes had resistances of 4-7 M $\Omega$. M/T cells were identified by size and location of their somata and filled with Lucifer Yellow during patch recording. The intracellular solution contained: $140 \mathrm{mM} \mathrm{KCl}, 1 \mathrm{mM}$ EGTA, $10 \mathrm{mM}$ HEPES, $1 \mathrm{mM}$ ATP Na-salt, $0.5 \mathrm{mM}$ GTP Mg-salt, $0.1 \mathrm{mM}$ Lucifer Yellow; $\mathrm{pH}$ 7.1, $290 \mathrm{mOsm}$. M/T cells were held at -55 to $-60 \mathrm{mV}$. Input and series resistances were 200-300 $\mathrm{M} \Omega$ and 15-20 $\mathrm{M} \Omega$, respectively. After establishing a whole-cell recording, the ONL was stimulated using a glass electrode (1-1.5 M $\Omega$ ) filled with HEPES-buffered extracellular solution connected to an electrical stimulator (single stimulus: $20 \mathrm{~ms}, 40 \mathrm{~V}, 266-400 \mu \mathrm{A}$ ). The stimulus pipette was placed rostrally to the recorded cell in the ONL. If a given M/T cell showed no postsynaptic response, the position of the stimulus pipette was changed until OSN axon bundles were found that caused M/T cell responses. Ionic currents were analysed using PulseFit 8.54 (HEKA) and IGOR Pro software (Wavemetrics) ${ }^{36}$. OSNs with leak currents $>20 \mathrm{pA}$ and $\mathrm{M} / \mathrm{T}$ cells with leak currents $>100 \mathrm{pA}$ (all measured at $-70 \mathrm{mV}$ ) were excluded from analysis. Cell capacitance $\left(C_{\mathrm{m}}\right)$ was monitored using the automated function of the EPC-9 amplifier. A stable $C_{\mathrm{m}}$ value over time was an important criterion for the quality of an experiment. Spike analysis was done off-line using IGOR Pro software with customwritten macros. Chemicals were purchased from Sigma unless otherwise stated. Drugs used in the electrophysiological experiments were prepared as stock solutions in DMSO or distilled water and diluted to the final concentration in HEPES-based extracellular solution. $\mathrm{NaCl}, \mathrm{MgCl}_{2}$, glucose and $\mathrm{CaCl}_{2}$ were from Merck. IBMX $(100 \mu \mathrm{M})$ and cineole $(100 \mu \mathrm{M})$ were diluted in a HEPES-buffered extracellular solution $(<0.1 \%$ DMSO $)$ and focally ejected using multibarrel stimulation pipettes.

\section{Behavioural tests}

The innate olfactory preference test followed previously described procedures ${ }^{31}$. Briefly, mice were habituated to the test conditions before odour exposure. Mice were individually placed in an empty cage for $30 \mathrm{~min}$ and then transferred to a new cage. This habituation was repeated three to four times for each animal. Soon after habituation, mice were transferred to 
the test cage, and a filter paper scented with a test odorant was introduced. Investigation times of the filter paper during the 3-min test period was recorded and quantified. Odour stimuli were freshly collected male and female B6 mouse urine $(5 \mu \mathrm{l})$, peanut butter (10\% $\mathrm{w} / \mathrm{v}, 15 \mu \mathrm{l})$, milk powder $(10 \% \mathrm{w} / \mathrm{v}, 15 \mu \mathrm{l})$, water $(15 \mu \mathrm{l})$ and cineole $(100 \mu \mathrm{M}, 15 \mu \mathrm{l})$.

For the innate olfactory avoidance test, following habituation (see innate preference test), a filter paper scented with $5 \mu 1$ TMT $(7.6 \mathrm{mM})$ was placed in one corner of the test cage. Mouse behaviour was recorded for $30 \mathrm{~min}$. The test cage was subdivided into three equally sized areas. Time spent in area 1 of the cage (farthest distance from the TMT source) was evaluated as avoidance, whereas time spent in area 2 (consisting of the TMT source) was evaluated as attraction ${ }^{37}$. Animal movements were tracked with SwisTrack (Swarm Intelligent Systems Group, Swiss Federal Institute of Technology).

For the olfactory habituation-dishabituation assay, following habituation (see innate preference test) mice were exposed for 3 min to distilled water $(15 \mu \mathrm{l})$. This procedure was repeated three times with 1-min intervals, followed by a three-time presentation of female urine $(5 \mu \mathrm{l})$ and a three-time presentation of male urine $(5 \mu \mathrm{l})$. Investigation times during the 3 -min test periods were measured.

For the pup retrieval test, lactating mice were habituated to the experiment for several minutes. Experiments were performed in the bedded home cages of the dams. Three pups (1-3-days old) were removed from the nest and randomly distributed in the cage. The latency for pup retrieval back into the nest was measured. If a dam had not completed retrieval within $10 \mathrm{~min}$ the test was terminated, resulting in a latency of $600 \mathrm{~s}$.

Experiments were performed in empty standard cages $(38 \times 19 \times 12 \mathrm{~cm})$ and test substances were applied on filter paper $(\sim 1 \times 3 \mathrm{~cm})$. Mouse behaviour was recorded with a digital camera (Sony) for the experimental times indicated. Statistical video analyses were done randomly and blindly. Peanut butter (Barney's Best) and milk powder (Bio-Anfangsmilch, Hipp) were diluted to $10 \%(w / v)$ in water.

\section{IGF-1 assays}

IGF-1 levels were measured by sandwich ELISA (ALPCO Diagnostics). IGF-1 was dissociated from the binding proteins by diluting samples with an acidic buffer. The analytical sensitivity of the assay was $0.029 \mathrm{ng} \mathrm{ml}^{-1}$. Inter and intra-assay variability was below 7\%. Experiments used plasma of 4-5-weeks-old mice ( $n=4$, each genotype).

\section{Statistics}

Data were analysed using NCSS 2004 statistical software (NCSS). The Student's $t$-test (twotailed) was used for measuring the significance of difference between two distributions. Multiple groups were compared using a one-way or two-way analysis of variance (ANOVA) with Fisher's LSD as a post hoc comparison. Unless otherwise stated, results are presented as means \pm s.e.m.

\section{Supplementary Material}

Refer to Web version on PubMed Central for supplementary material.

\section{Acknowledgments}

We thank the individuals who participated in this study, P. Mombaerts for supplying OMP-Cre and OMP-GFP
mice, F. Margolis for anti-OMP antibodies, J. Epelbaum for supporting the IGF-1 measurements, P. Hammes for
assistance with the immunohistochemistry and C. Kaliszewski for assistance with the electron microscopy. This
work was supported by grants from the Deutsche Forschungsgemeinschaft (DFG) to F.Z. (SFB 530 and SFB 894) 
and T.L.-Z. (SFB 894). E.J. was supported by the DFG-fundedInternational GraduateSchool GK 1326. T.L.-Z. is a Lichtenberg Professor of the Volkswagen Foundation. J.N.W. was supported by the Biotechnology and Biological Sciences Research Council, Medical Research Council, Wellcome Trust and grant number R31-2008-000-10103-0 from the World Class University project of the Korean Ministry of Education, Science and Technology and the National Research Foundation of Korea.

\section{References}

1. Hasin-Brumshtein Y, Lancet D, Olender T. Human olfaction: from genomic variation to phenotypic diversity. Trends Genet. 2009; 25:178-184. [PubMed: 19303166]

2. Feldmesser E, et al. Mutations in olfactory signal transduction genes are not a major cause of human congenital general anosmia. Chem Senses. 2007; 32:21-30. [PubMed: 17008420]

3. Keller A, Vosshall LB. Better smelling through genetics: mammalian odor perception. Curr Opin Neurobiol. 2008; 18:364-369. [PubMed: 18938244]

4. Goldin AL. Resurgence of sodium channel research. Annu Rev Physiol. 2001; 63:871-894. [PubMed: 11181979]

5. Catterall WA, Goldin AL, Waxman SG. International Union of Pharmacology. XLVII Nomenclature and structure-function relationships of voltage-gated sodium channels. Pharmacol Rev. 2005; 57:397-409. [PubMed: 16382098]

6. Cox JJ, et al. An $S C N 9 A$ channelopathy causes congenital inability to experience pain. Nature. 2006; 444:894-898. [PubMed: 17167479]

7. Goldberg YP, et al. Loss-of-function mutations in the $\mathrm{Na}_{\mathrm{v}} 1.7$ gene underlie congenital indifference to pain in multiple human populations. Clin Genet. 2007; 71:311-319. [PubMed: 17470132]

8. Ahmad S, et al. A stop codon mutation in SCN9A causes lack of pain sensation. Hum Mol Genet. 2007; 16:2114-2121. [PubMed: 17597096]

9. Dib-Hajj SD, Cummins TR, Black JA, Waxman SG. From genes to pain: $\mathrm{Na}_{\mathrm{V}} 1.7$ and human pain disorders. Trends Neurosci. 2007; 30:555-563. [PubMed: 17950472]

10. Nilsen KB, et al. Corrigendum to "Two novel SCN9A mutations causing insensitivity to pain. Pain. 2009; 145:264.

11. Munger SD, Leinders-Zufall T, Zufall F. Subsystem organization of the mammalian sense of smell. Annu Rev Physiol. 2009; 71:115-140. [PubMed: 18808328]

12. Nassar MA, et al. Nociceptor-specific gene deletion reveals a major role for $\mathrm{Na}_{\mathrm{V}} 1.7$ (PN1) in acute and inflammatory pain. Proc Natl Acad Sci USA. 2004; 101:12706-12711. [PubMed: 15314237]

13. Li J, Ishii T, Feinstein P, Mombaerts P. Odorant receptor gene choice is reset by nuclear transfer from mouse olfactory sensory neurons. Nature. 2004; 428:393-399. [PubMed: 15042081]

14. Klugbauer N, Lacinova L, Flockerzi V, Hofmann F. Structure and functional expression of a new member of the tetrodotoxin-sensitive voltage-activated sodium channel family from human neuroendocrine cells. EMBO J. 1995; 14:1084-1090. [PubMed: 7720699]

15. Morinville A, et al. Distribution of the voltage-gated sodium channel $\mathrm{Na}_{\mathrm{V}} 1.7$ in the rat: expression in the autonomic and endocrine systems. J Comp Neurol. 2007; 504:680-689. [PubMed: 17722032]

16. Baker H, Grillo M, Margolis FL. Biochemical and immunocytochemical characterization of olfactory marker protein in the rodent central nervous system. J Comp Neurol. 1989; 285:246-261. [PubMed: 2760264]

17. Belluscio L, Gold GH, Nemes A, Axel R. Mice deficient in $\mathrm{G}_{\mathrm{olf}}$ are anosmic. Neuron. 1998; 20:69-81. [PubMed: 9459443]

18. Zhao H, Reed RR. X inactivation of the OCNC1 channel gene reveals a role for activity-dependent competition in the olfactory system. Cell. 2001; 104:651-660. [PubMed: 11257220]

19. Spehr M, et al. Essential role of the main olfactory system in social recognition of major histocompatibility complex peptide ligands. J Neurosci. 2006; 26:1961-1970. [PubMed: $16481428]$

20. Leinders-Zufall T, et al. Contribution of the receptor guanylyl cyclase GC-D to chemosensory function in the olfactory epithelium. Proc Natl Acad Sci USA. 2007; 104:14507-14512. [PubMed: 17724338] 
21. Munger SD, et al. Central role of the $\mathrm{CNGA} 4$ channel subunit in $\mathrm{Ca}^{2+}$-calmodulin-dependent odor adaptation. Science. 2001; 294:2172-2175. [PubMed: 11739959]

22. Shepherd, GM.; Chen, WR.; Greer, CA. The Synaptic Organization of the Brain. Shepherd, GM., editor. Oxford Univ. Press; 2004. p. 165-216.

23. Wachowiak M, Shipley MT. Coding and synaptic processing of sensory information in the glomerular layer of the olfactory bulb. Semin Cell Dev Biol. 2006; 17:411-423. [PubMed: 16765614]

24. Nickell WT, Shipley MT, Behbehani MM. Orthodromic synaptic activation of rat olfactory bulb mitral cells in isolated slices. Brain Res Bull. 1996; 39:57-62. [PubMed: 8846109]

25. Gabellec MM, Panzanelli P, Sassoe-Pognetto M, Lledo PM. Synapse-specific localization of vesicular glutamate transporters in the rat olfactory bulb. Eur J Neurosci. 2007; 25:1373-1383. [PubMed: 17425564]

26. Richard MB, Taylor SR, Greer CA. Age-induced disruption of selective olfactory bulb synaptic circuits. Proc Natl Acad Sci USA. 2010; 107:15613-15618. [PubMed: 20679234]

27. Yu CR, et al. Spontaneous neural activity is required for the establishment and maintenance of the olfactory sensory map. Neuron. 2004; 42:553-566. [PubMed: 15157418]

28. Puche AC, Shipley MT. Odor-induced, activity-dependent transneuronal gene induction in vitro: mediation by NMDA receptors. J Neurosci. 1999; 19:1359-1370. [PubMed: 9952413]

29. Cho JY, Min N, Franzen L, Baker H. Rapid down-regulation of tyrosine hydroxylase expression in the olfactory bulb of naris-occluded adult rats. J Comp Neurol. 1996; 369:264-276. [PubMed: 8726999]

30. Baker H, et al. Targeted deletion of a cyclic nucleotide-gated channel subunit (OCNC1): biochemical and morphological consequences in adult mice. J Neurosci. 1999; 19:9313-9321. [PubMed: 10531436]

31. Kobayakawa K, et al. Innate versus learned odour processing in the mouse olfactory bulb. Nature. 2007; 450:503-508. [PubMed: 17989651]

32. Wesson DW, Levy E, Nixon RA, Wilson DA. Olfactory dysfunction correlates with amyloid- $\beta$ burden in an Alzheimer's disease mouse model. J Neurosci. 2010; 30:505-514. [PubMed: 20071513]

33. Sakano H. Neural map formation in the mouse olfactory system. Neuron. 2010; 67:530-542. [PubMed: 20797531]

34. Pyrski M, et al. Sodium/calcium exchanger expression in the mouse and rat olfactory systems. J Comp Neurol. 2007; 501:944-958. [PubMed: 17311327]

35. Au WW, Treloar HB, Greer CA. Sublaminar organization of the mouse olfactory bulb nerve layer. J Comp Neurol. 2002; 446:68-80. [PubMed: 11920721]

36. Ukhanov K, Leinders-Zufall T, Zufall F. Patch-clamp analysis of gene-targeted vomeronasal neurons expressing a defined V1r or V2r receptor:ionic mechanisms underlying persistent firing. J Neurophysiol. 2007; 98:2357-2369. [PubMed: 17715188]

37. Papes F, Logan DW, Stowers L. The vomeronasal organ mediates interspecies defensive behaviors through detection of protein pheromone homologs. Cell. 2010; 141:692-703. [PubMed: 20478258] 
a
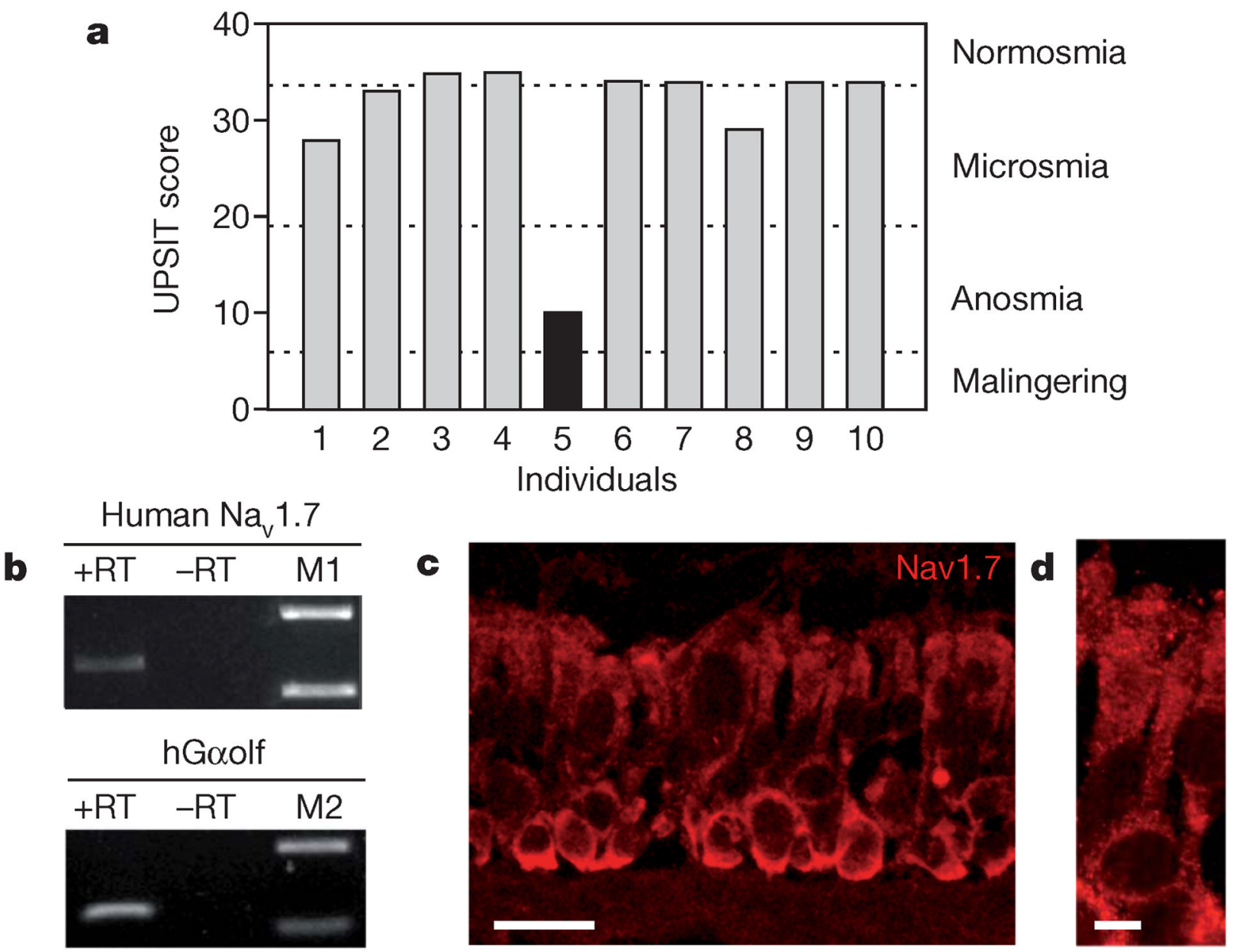

Figure 1. $\mathrm{Na}_{\mathrm{v}} \mathrm{1.7}$ in human olfaction

a, Quantified olfactory assessment of the first individual with confirmed $\mathrm{Na}_{\mathrm{v}} 1.7$ loss-offunction mutations (black bar) using the standardized, 40-item UPSIT test showed that she was unable to detect any of the odour stimuli; the test score revealed general anosmia in this patient. Nine healthy, young individuals served as controls (grey bars). We assessed odour perception in two other individuals with confirmed $\mathrm{Na}_{\mathrm{v}} 1.7$ loss-of-function mutations and both were unable to sense any of the odours. These results are described in the main text. b, Expression of $\mathrm{Na}_{\mathrm{v}} 1.7$ in olfactory epithelium from unaffected normal humans. RT-PCR products with gene-specific primers for human $\mathrm{Na}_{\mathrm{V}} 1.7$ (top; size, 1,128 bp) and the Gprotein $\mathrm{Ga}_{\text {olf }}$ (bottom; size, $143 \mathrm{bp}$ ). PCRs were carried out with equal amounts of RNA in the presence $(+\mathrm{RT})$ or absence $(-\mathrm{RT})$ of reverse transcriptase to exclude product amplification from genomic DNA. M1, size marker; 2,000 bp, 850 bp; M2, size marker; 400 bp, 100 bp. Similar results were obtained in two other human olfactory mucosa samples. c, Confocal fluorescence image of $\mathrm{Na}_{\mathrm{v}} 1.7$ immunoreactivity (red) in a cryosection of human olfactory epithelium. Scale bar, $20 \mu \mathrm{m}$. d, Enlargement showing a single OSN. Scale bar, 5 $\mu \mathrm{m}$. 


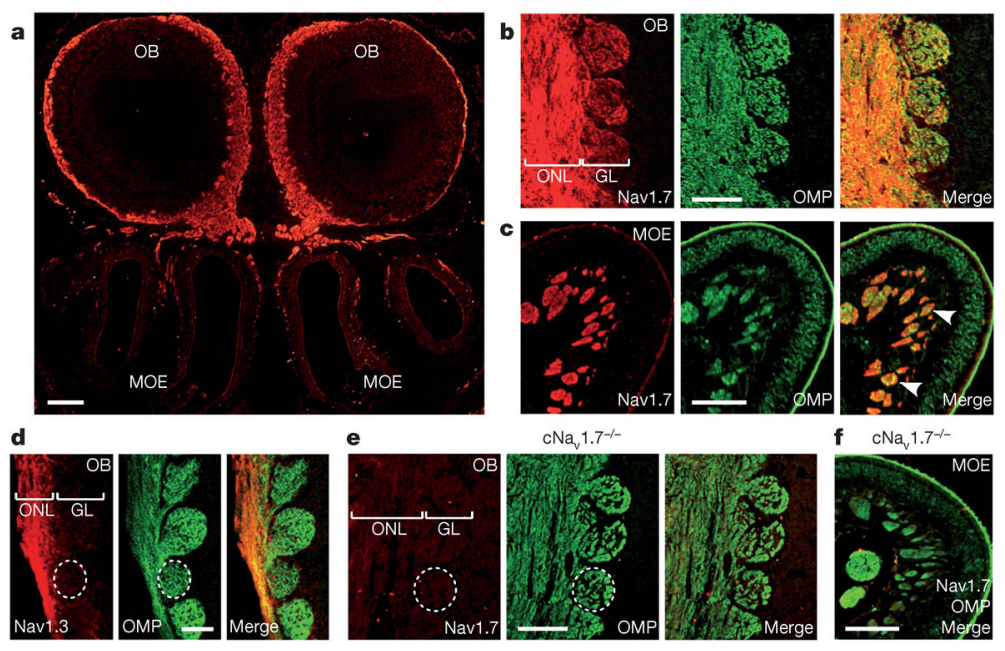

Figure 2. $\mathrm{Na}_{\mathrm{v}} 1.7$ expression in the mouse main olfactory system

a, $\mathrm{Na}_{\mathrm{v}} 1.7$ immunoreactivity (red) detected in the olfactory bulbs (OB, top) and the underlying main olfactory epithelium (MOE, bottom). B6 mouse, 2-days old. b,

Colocalization of $\mathrm{Na}_{\mathrm{v}} 1.7$ (red) and OMP (green) expression in the ONL and glomerular layer (GL) of the olfactory bulb. B6 mouse, 3-weeks old. c, Strong $\mathrm{Na}_{\mathrm{v}} 1.7$ immunoreactivity in OSN axon bundles (arrowheads). B6 mouse, 3-weeks old. d, $\mathrm{Na}_{\mathrm{v}} 1.3$ expression (red) terminates in the ONL and is not detectable in OMP-labelled (green) glomeruli. OMP-GFP mouse, 16-days old. e-f, $\mathrm{cNa}_{\mathrm{v}} 1.7$ mice lack $\mathrm{Na}_{\mathrm{v}} 1.7^{-/-}$immunoreactivity in the ONL and glomerular layer of the olfactory bulb (e) as well as in OSN axon bundles of MOE (f). Dashed circle, individual glomerulus. Scale bars: a, $200 \mu \mathrm{m} ; \mathbf{b}, \mathbf{c}, \mathbf{e}, \mathbf{f}, 100 \mu \mathrm{m} ; \mathbf{d}, 50 \mu \mathrm{m}$. 
a
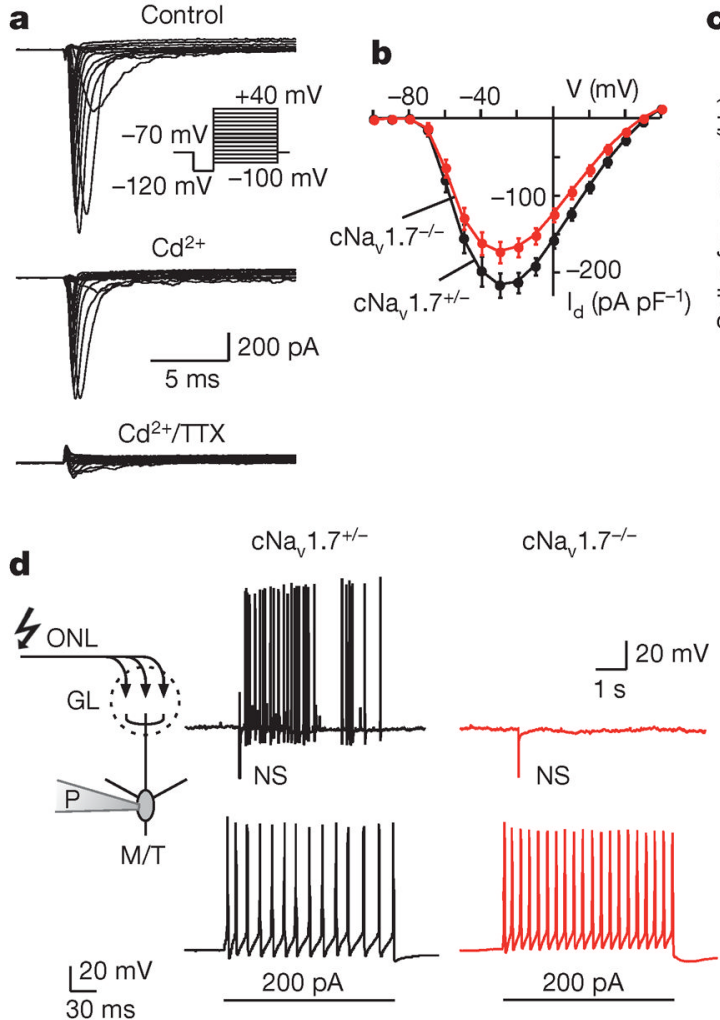

h

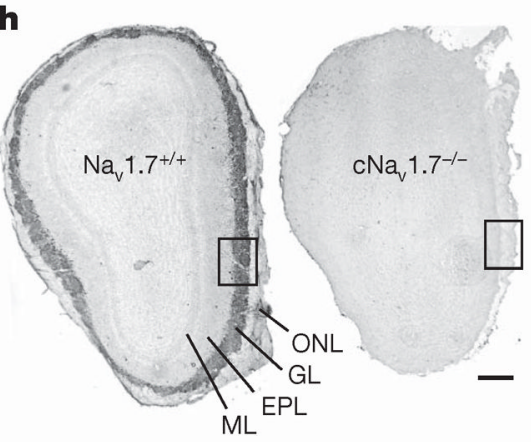

c

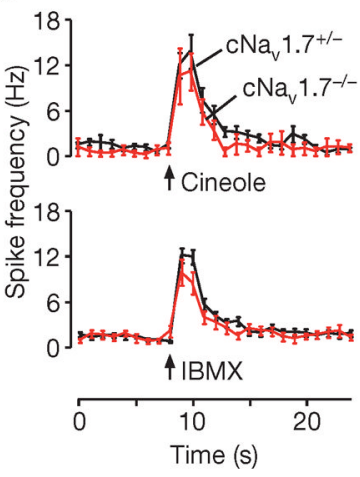

e

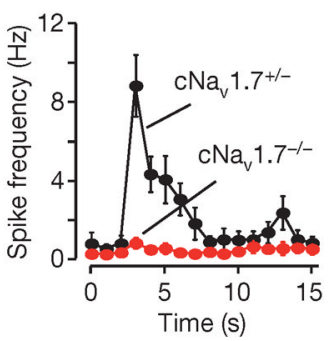

f $\mathrm{CNa}_{\mathrm{v}} 1.7^{+/ 2}$
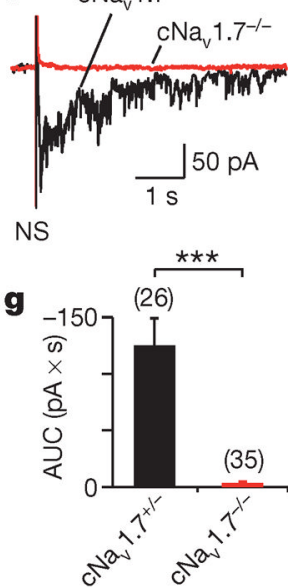

Figure 3. $\mathrm{Na}_{\mathbf{v}} \mathbf{1 . 7}$ is essential for synaptic transfer in the olfactory glomerulus a, Families of whole-cell currents to a series of depolarizing voltage steps recorded from $\mathrm{cNa}_{\mathrm{v}} 1.7^{-/-}$OSNs. OSNs were exposed successively to extracellular bath solution (control), bath solution containing $\mathrm{Cd}^{2+}(100 \mu \mathrm{M})$, and bath solution containing $\mathrm{Cd}^{2+}(100 \mu \mathrm{M})$ and TTX $(2 \mu \mathrm{M})$. Holding potential, $-70 \mathrm{mV}$. b. Current-density-voltage curves of sodium currents from $\mathrm{cNa}_{\mathrm{v}} 1.7^{+/-}$(black; $n=35$ ) and $\mathrm{cNa}_{\mathrm{v}} 1.7^{-/-}$OSNs (red; $n=46$ ). Current densities of $\mathrm{Na}_{\mathrm{v}} 1.7^{+/-}$OSNs were significantly diminished between $-30 \mathrm{mV}$ and $10 \mathrm{mV}$ (LSD, $P=0.001-0.04)$. c, Action potential responses in visually identified OSN dendritic knobs to pulsed stimulation $(0.2 \mathrm{~s})$ with cineole $(100 \mathrm{M})$ or IBMX (100 respectively) and $\mathrm{cNa}_{\mathrm{v}} 1.7^{+/-} \mu$ (black; $n=28$ and 78 cells, $\mu \mathrm{M}$ ) in $\mathrm{cNa}_{\mathrm{v}} 1.7^{-/-}$OSNs (black; $n=5$ and 25 , respectively). Firing properties were similar in both genotypes (LSD, $P=0.14-0.73$ ). d, M/T cells exhibit postsynaptic potentials to presynaptic nerve stimulation (NS) in $\mathrm{cNa}_{\mathrm{v}} 1.7^{+/-}$ (black), but not in $\mathrm{cNa}_{\mathrm{v}} 1.7^{-/}$mice (red), whereas $\mathrm{M} / \mathrm{T}$ cells in both genotypes show normal action potentials to current injection (200 pA). Current-clamp whole-cell recording. e, 
Absence of M/T cell postsynaptic potentials to nerve stimulation in $\mathrm{cNa}_{\mathrm{v}} 1.7^{-/-}$(red; $\left.n=44\right)$ versus $\mathrm{cNa}_{\mathrm{v}} 1.7^{+/-}$(black; $\left.n=29\right)(\mathrm{LSD}, P<0.01-0.001)$. f, Example of postsynaptic currents in $\mathrm{M} / \mathrm{T}$ cells of $\mathrm{cNa}_{\mathrm{v}} 1.7^{+/-}$(black) and $\mathrm{cNa}_{\mathrm{v}} 1.7^{-/-}$mice (red). $\mathrm{g}$, Analysis of area under curve (AUC) of $\mathrm{M} / \mathrm{T}$ cell postsynaptic currents during a $5 \mathrm{~s}$ interval after nerve stimulation in $\mathrm{cNa}_{\mathrm{v}} 1.7^{+/-}$(black) and $\mathrm{cNa}_{\mathrm{v}} 1.7^{-/-}$mice (red). Number of cells tested is shown in brackets above each bar. Unpaired $t$-test: $* * * P<0.0001$. h, Marked reduction of $\mathrm{TH}$ expression in juxtaglomerular cells of the olfactory bulb in $\mathrm{cNa}_{\mathrm{v}} 1.7^{-/-}$mice. EPL, external plexiform layer; ML, mitral cell layer. Arrows in the inset $(+/+)$ indicate individual juxtaglomerular cells. Scale bars: overview, $100 \mu \mathrm{m}$; inset, $50 \mu \mathrm{m}$. Error bars represent mean \pm s.e.m. 
a

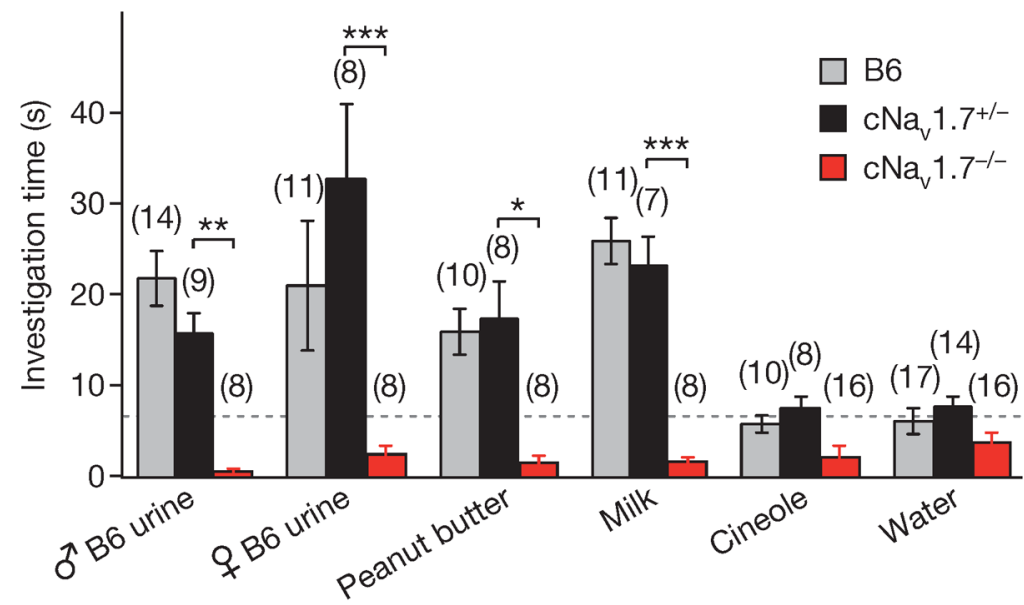

b

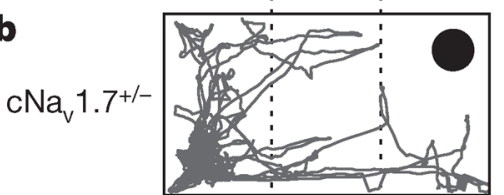

$\mathrm{cNa}_{\mathrm{v}} 1.7^{-\prime}$

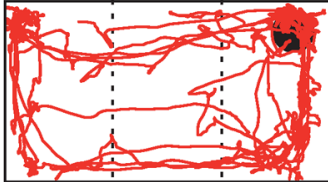

Avoid (-)

area 1 area 2
Attract (+)

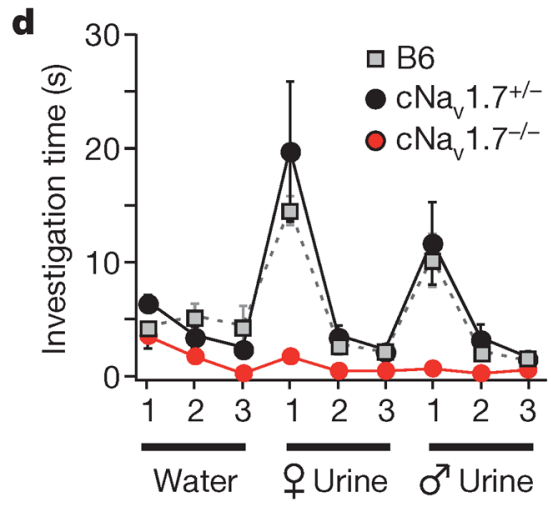

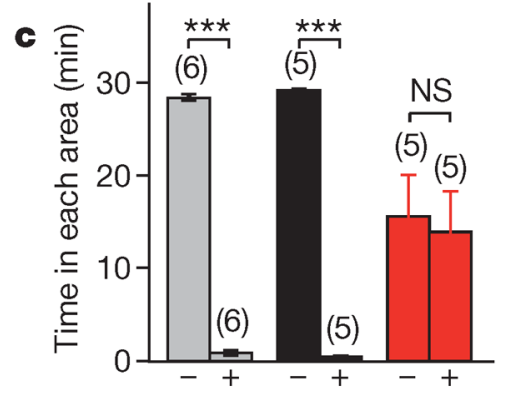

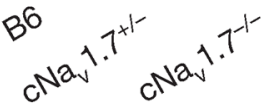

e

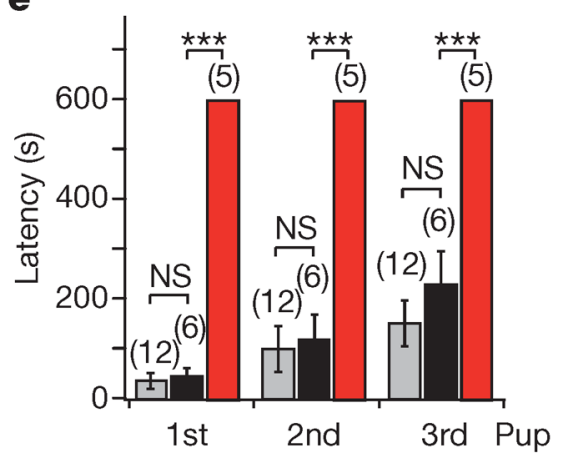

Figure 4. $\mathrm{cNa}_{\mathrm{v}} 1.7^{-/-}$mice are anosmic

a, Innate olfactory preference test. Mean investigation times were quantified in B6, $\mathrm{cNa}_{\mathrm{v}} 1.7^{+/-}$and $\mathrm{cNa}_{\mathrm{v}} 1.7^{-/-}$mice during a 3-min test period. Mean investigation time for water in $\mathrm{B} 6$ and $\mathrm{cNa}_{\mathrm{v}} 1.7^{+/-}$mice (dashed line) served as a marker for attraction. Number of animals tested is shown in brackets above each bar. LSD: $* P<0.02$; $* * P<0.001$; *** $P<$ 0.0001. No difference was observed between $\mathrm{B} 6$ and $\mathrm{cNa}_{\mathrm{v}} 1.7^{+/-}$mice (LSD, $P=0.1$ ). $\mathbf{b}, \mathrm{c}$, Innate olfactory avoidance to the predator odour TMT. b, Examples of the trajectory plot of the position of a cNa $1.7^{+/-}$and a $\mathrm{cNa}_{\mathrm{v}} 1.7^{-/-}$mouse (30-min video-tracking). Location of TMT $(5 \mu l)$ indicated by the circle in the upper right corner. c, Quantification of time spent in either area $1(-)$ or area $2(+)$ during exposure to TMT indicates that $\mathrm{cNa}_{\mathrm{v}} 1.7^{-/-}$mice lack avoidance behaviour to TMT (LSD, $P=0.67$ ). LSD: $* * * P<0.0001$. d, Olfactory habituation-dishabituation assay. Mean investigation time of $\mathrm{B} 6, \mathrm{cNa}_{\mathrm{v}} 1.7^{+/-}$and $\mathrm{cNa}_{\mathrm{v}} 1.7^{-/-}$ 
mice ( $n=8$ for each group) to three distinct stimuli (water, female and male mouse urine) during a 3-min test period were quantified. Numbers indicate stimulus presentation order. e, Pup retrieval test. Mean latencies of $\mathrm{B} 6, \mathrm{cNa}_{\mathrm{v}} 1.7^{+/-}$and $\mathrm{cNa}_{\mathrm{v}} 1.7^{-/-}$female mice in retrieving three individual pups that were randomly distributed throughout the cage. $\mathrm{cNa}_{\mathrm{v}} 1.7^{-/-}$mice failed to retrieve any of the pups during a 10-min trial period (LSD, $P<$ 0.0001 ). NS, not significant (LSD, $P=0.41$ ). Error bars represent mean \pm s.e.m. 